\title{
DEN SANNA HISTORIEN OM TOMMY OCH REFLEKTIONER AV DIREKTÖREN FÖR ETT UNGDOMSFÄNGELSE
}

AV FÄNGELSEDIREKTÖR KIRSTI NIEMINEN

Tommy is a 27 year-old Finnish man who is imprisoned for the third time. His story is an illuminating example of gradual social displacement beginning at a very early age. Tommy's antisocial behaviour reflects insufficient or incorrect care received from his primary family; experiences of violence, humiliation, and loneliness; indifference and incompetence on the part of public authorities; and his own substance abuse and need for showing off. Tommy is now going through an intensive community treatment programme in Kerava prison, and is starting to believe in his possibilities to adopt a more pro-social way of living.

The majority of Finnish offenders share Tommy's story in the respect that their criminal careers have not been a sudden choice, but rather the sum of many accumulating negative factors. This fact is to some extent taken into account in the Finnish penal system. A child under 15 years of age cannot be convicted of a crime, but is instead turned over to the child welfare sector. Young offenders from 15 to 21 years of age serve only one-third of their sentences, and do so in a separate young offender's unit. A young offender under 18 years of age is sentenced to prison only for very severe crimes. The more lenient sentencing practise for young offenders is based on the view that unconditional imprisonment increases the probability of recidivism.

Tommy's story so far has had many sad chapters, but luckily it is not too late to change the tale. It is possible to break the cycle of substance abuse and antisocial lifestyle even in prison via treatment programmes that are carefully designed and intensively administered. In order to prevent the sad parts of Tommy's tale from repeating themselves in other children's lives, a comprehensive support system for families is needed. Interventions should begin early, when clear behavioural problems are first noticed. The support system should be built on multi-professional cooperation between public authorities, non-governmental organizations, congregations, and families. ${ }^{*}$

\footnotetext{
* Title in English: Tommy's Tale - A True Story: Reflections by the Director of a Youth Prison. Original in Swedish.
} 


\section{Historien om Tommy}

Tommy är 27 år vid tidpunkten för intervjun. Han avtjänar för närvarande sitt tredje straff i Kervo fängelse. Tommy föddes i Göteborg dit hans finländska föräldrar hade flyttat 1976. De hade flytt från Tammerfors, bort från det ogillande som mammans släktingar visade. Tommys pappa var inte omtyckt. En långhårig hippiemusiker var inte lämplig för den unga dottern i en medelklass-familj.

Tommys pappa började jobba på Volvo i Göteborg, och mamman stannade hemma när hon väntade Tommy. Tommy har egentligen inga minnesbilder från tiden i Sverige. Det enda han kommer ihåg är att man lekte på svenska. När familjen om några år flyttade tillbaka till Tammerfors, talade Tommy bara svenska. Men på gårdplanen vid det stora höghuset anpassade sig den livlige Tommy snabbt till gårdskulturen i Hervanta i Tammerfors. Det enda Tommy kommer ihåg från tiden före skolan var att mamma och pappa ständigt skrek och att pappa drack.

När Tommy som sjuåring började skolan, skildes föräldrarna. Mamma började jobba treskift som servitris. Den första klassen beredde den livlige Tommy inga svårigheter. Men han kände ett stort behov att stå på sig på skolgården. I den andra klassen fick Tommy en ny stillsam kvinnlig lärare från Lappland som inte kunde stå ut med vilda barn. Svårigheterna började, och modern fick ofta samtal till jobbet från skolan. Mamman försvarade sin son vilket läraren ogillade. Tommy hade inga inlärningssvårigheter. För att undvika de tråkiga erfarenheterna i skolan och lärarens straff började Tommy rymma från skolan till det tomma hemmet. Hemma kunde man vara i fred, för mamma jobbade vid den tiden mycket och det behövdes pengar. Mammas arbetskompisar besökte hemmet under fritiden, och man drack mycket alkohol.

Sedan flyttade mammas nye pojkvän in i hemmet. Tommy har många trista minnen av mannen som var yngre än mamma men hade ett bra jobb. Mannen gjorde ett tilltalande offentligt intryck på mammas släktingar. Mannen visade gärna mamma och mammas arbetskompisar hur bra han kunde övervaka Tommy som han ansåg vara alltför livlig.

Den tredje klassen hade börjat, och det bekanta gänget på gården i Hervanta hade lärt sig röka. Styvfadern gav stryk för rökförsöken och andra förseelser hemma hos Tommy - det skedde högljutt och i närvaron av gäster. De obehagliga känslorna tog sig utlopp i skolan, och det kom allt oftare hem telefonsamtal som gällde problem med läraren. Hemma ledde samtalen till skrik, stryk och arreststraff. Tommy blev överförd till en observationsklass i en annan skola. Där fanns det fem eller sex elever, men alla hade många problem. Det säger Tommy, när han går igenom sina minnesbilder. Livet hemma fortsatte med många svårigheter. Mamman och styvfadern skrek till varandra och till Tommy. Moderns bror brukade hämta Tommy för att åka slalom eller göra något annat 
trevligt, men nu var det slut med det, när mamma ville dölja sina egna problem och Tommys skolsvårigheter för släkten.

Tommy fortsatte visserligen att besöka den egna farmodern och hennes bror på landet. Från den tiden har Tommy flera sommarminnen. Farmor förde honom till badstranden, och han minns att farmor kunde ligga och flyta på vattnet hur länge som helst. Men vistelsen hos farmor lämnade ett tärande vemod över att de vuxna bara stökade med sina egna saker - utan att lägga märke till Tommy. Tommy blev visserligen uppmärksammad av mammas arbetskompisar. Och på släktbjudningar var Tommy det enda barnet, och därför tyckte han att han blev föremål för överdriven uppmärksamhet. Alla andra var vuxna - det fanns inga barn i moderns släktkrets, och Tommy längtade efter jämnårigt sällskap.

Gänget kring höghusen blev allt viktigare för Tommy, även om det inte fanns några riktiga vänner där. Situationen blev inte bättre av att många föräldrar ansåg Tommy vara dåligt sällskap för deras egna barn. Tommy fick förstås nya vänner i observationsklassen. Det gjorde överraskande nog också Tommys mamma. Mamman var rädd när Tommy överfördes till observationsklassen. Tommy minns att mamma fällde många tårar på grund av överföringen. Men när det visade sig att sonen till en av mammans arbetskompisar också gick i samma klass, slutade tårarna. Mammorna blev vänner. Lektionerna var enkla för Tommy, men dumheterna med kompisarna började störa ordningen i skolan. Gänget började alltmer vandalisera affärer och platser nära skolan. Man sysslade med olika sorters skadegörelse och snattade varor i butikernas bakrum. Vanligen greps ingen i gänget. Kompisarna i skolan och på gården rökte och snusade. När man blev fast, blev man luggad av läraren som ringde hem. Hemma följde skrik, arrest och stryk av styvfadern. Upprepade kropps- och arreststraff ökade motviljan mot karlen. Rökningen blev en vana. Tommys uppror tog sig därefter uttryck i att han började experimentera med alkohol. Hemma var det lätt att hälla sprit från de talrika flaskorna i en stor saftdunk, och blandningen delades med gänget på gården. Tommys fysik stod ut med mera sprit än kompisarnas. Visst hade det funnits bättre fritidsalternativ. Tommy var speciellt intresserad av fotboll, men styvfadern förhindrade alla fritidsintressen. Tommy lyckades i smyg anmäla sig till en fotbollsklubb. Men han fick aldrig delta i träningarna när styvfadern fått reda på saken. Dumheterna i skolan avbröts i någon mån av sommarlovet $\mathrm{i}$ en sommarkoloni. Där hade Tommy mycket sällskap i sin egen ålder. Det rådde sommarfröjd under ferierna, och mamma fick andas ut ett tag hemma. Tommy har flera angenäma minnen från dessa perioder.

I den fjärde klassen fortsatte skolkningen och det andra ofoget med kompisarna. Det gjorde också rökningen och sjabblet med sprit. Mamman lade inte märke till den felande spritmängden hemma, eftersom grälen mellan henne och pojkvännen hade skärpts och tagit våldsamma former. Pojkvännen slog nu också 
mamman med hemska skrik som följd. Tommy fick allt oftare stryk - för ingenting. Styvfar ville visa mamma. Och mamman vågade inte försvara sin son. Efter ett hemskt gräl hade mannen en gång lagt beslag på mammas nyckel och drivit henne ut på balkongen. Mamma ropade att hon tänkte hoppa. Också Tommy lyckades nå balkongen och bad henne uppskrämt att inte hoppa. Scenen var därmed slut, och pojkvännen flyttade snart ut. Men incidenten satte ett varaktigt spår i Tommys själsliv. Nu började Tommy intressera sig för kick-boxing och taekwondo. Men också de dåliga fritidssysselsättningarna fanns kvar. Tommy besökte styvfaderns sommarstuga med kompisarna - allt värdefullt stals och lokalen förstördes grundligt. Det var en hämnd. Ingen ställde några frågor senare. Tommys egen pappa började igen träffa Tommy och ta honom med sig på spelningar överallt i Finland (efter att ha kommit överens med mamman om arrangemangen). Ibland besökte de djurparken i Etseri, ibland Rukka eller något annat skidcentrum, ibland var de på Sverigebåtarna osv. Tommy minns att han vid den tiden brukade se familjefilmer när han var ensam. I filmerna levde papporna med familjen och uppmuntrade sina söner med helt vanliga saker. Och barnen klarade sig. Tommy hade aldrig sett några sådana familjer i det verkliga livet. Han hade inte heller upplevt den vänskap som beskrevs i filmerna. En verklig vänskap som klarade alla prövningar.

Höghuset där han bodde med mamma var fullt av alkoholistfamiljer och ensamstående föräldrar. I trappan sålde en fet kvinna tabletter till underåriga och alla intresserade. Tommy minns att kvinnan höll tabletterna i påsar. I hushållet fanns det dessutom en mager man, en liten son och en vild hund. Det var alltid lätt att ordna något program med alkohol och tabletter för gänget på gården.

I den femte klassen gick Tommy på nytt i en ny skola i centrum av Tammerfors. Det var igen i en observationsklass. Alla elever hade samma dåliga fritidssysselsättning. Under pauserna brukade man snatta i närbutikerna, men man greps inte längre. Gänget vistades gärna i centrum av Tammerfors, och Tommy blev känd som en påhittig och mottaglig lärjunge bland de "tuffa" killarna. Där fanns det många kompisar, men inga riktiga vänner. Observationsklasserna växlade under de kommande åren. Tommy brukade allt oftare bli borta från skolan som inte överhuvudtaget intresserade honom längre. Han upplevde sitt första tablett- och haschrus - och det välbefinnande det medförde! Modern underrättades om den upprepade frånvaron från skolan, och hon försökte ta över den försvunna styvfaderns roll och återställa disciplinen. Det kändes verkligt dåligt för Tommy. Mamma var honom så viktig och kär. Tommy kommer särkilt ihåg en gång när han kom hem, berusad av sprit och tabletter, och reagerade på mammans förebråelser genom att slå henne - sin mor. Tommy skämdes för det så mycket att han flera dagar höll sig borta hemifrån, han rentav tappade nyckeln. Han hade även tidigare hållit sig borta - hos kompisar och i trappupp- 
gångar. Men det här var nånting annat. Till slut mötte Tommy mamman på hennes jobb och bad om ursäkt. De kom hem tillsammans. Men problemen fortsatte. Mamman hade fått reda på att Tommy sniffade lim. Hon underrättade Tommys pappa som kom för att ge Tommy på käften. Det var den första gången, enligt vad Tommy senare berättade. Han blev så förskräckt att han slutade sniffa. Han hade ju hasch, tabletter och öl i stället. Han kunde festa och glömma skolan med sina nya kompisar som var lite äldre och diggade rock- och heavystjärnor. Tommy antog en livsstil som ingen kunde kritisera utan att bli föraktad eller angripen. De sociala myndigheterna började höra sig för om Tommys förehavanden. Men eftersom modern inte berättade något om sonens tilltag, ledde diverse anonyma angivelser ingenvart. Men man diskuterade både med modern och fadern. En häftigare erfarenhet skulle snart komma. Vid sidan av sjabblet med toluen och lim höll Tommy på med att plundra bärplockare och binda fast dem vid träd. Det var om just dessa dumheter socialarbetarna ville ställa frågor hemma hos Tommy. Även Tommys far var inbjuden för att diskutera frågan. Men Tommy uppenbarade sig plötsligt själv, och han var starkt berusad av tabletter. Tommy blev omedelbart tvångsomhändertagen. Han drogs i händer och fötter till en bil som väntade på gatan. Pappan drog honom i fötterna. Tommy sparkade och försökte bita angriparna. Mor bara skrek och grät.

I barnhemmet i Rauhanniemi bekantade Tommy sig med amfetamin. Men han övergav inte tabletter och hasch, tvärtom. Under sina äventyr i Tammerfors centrum var Tommy upptagen med att skaffa droger, och han hade bra kontakter. En äldre herre körde den snabbe och tyste penningkällan i en Buick tur och retur mellan barnhemmet och stadens centrum under kvällspermissionerna. Vårdarna förundrade sig visserligen över den fina biltransporten, men Tommy förklarade ingenting, och eftersom tidtabellerna höll, lät man saken bero. Det gick en buss från barnhemmet till skolan i Tammerfors centrum. Ända fram till matpausen trivdes eleverna kanske i skolan, men resten av dagen höll man till i staden och gjorde dumheter. Skolan ringde till barnhemmet, påföljden var arrest och städning. Skjutsning till skolan kombinerades med arresten, tills man efter en bestämd tid blev "tillåten" att åka buss igen. Ingenting förändrades - arreststraff och städning uppmuntrade knappast eleverna att försöka bättre. Men gänget gick in för en tuffare livsstil. Hasch röktes inte längre, amfetamin var bättre, och de brottsliga gärningarna planerades mera omsorgsfullt. Man höll sig borta från skolan flera dagar i sträck, ibland flera veckor. Kompisar, flickvänner och knarklangare kunde erbjuda nattlogi. Efter varje återförvisning till barnhemmet brukade vårdarna hitta knarkredskap och tablettburkar hos Tommy, men vårdarna teg. De tomma tablettburkarna fästes på anslagstavlan i Tommys rum. Därmed ville man ge ett tecken på att man visste, men annars rådde tystnad. Vård eller uppsökning av vård kom aldrig på tal. Det tycktes vara nog med att 
det gick bättre för andra adepter, även om Tommy försökte lära också de andra att röka hasch. Det fanns tre flickor och fem pojkar i barnhemmet vid den tiden. Dessutom alternerade småbarn oupphörligt. Tommy dolde sitt substansbruk för mamma genom att hålla sig till tabletter under besöken. Under de två år Tommy vistades i barnhemmet kom även pappa för att hämta Tommy under ledigheterna. Pappa hade en ny flickvän som hade en rolig blandrashund vid namn Pulla. Tommy har tydliga och glada minnen av dessa besök - farsan var inte heller full. Ledigheterna var den bästa tiden under barnhemsperioden. När Tommy blev uppmärksammad, blev hans humör bättre. Men vissa enskilda ledigheter med pappa på spelningar stärkte å andra sidan hans föreställning om heavyidoler, män av mafiosotypen med en whisky i handen omringade av vackra kvinnor. Kvinnor som definitivt behärskades av männen. Det enda positiva Tommy kommer ihåg från själva barnhemmet är de gånger man fick åka skidor. Far hade skaffat Tommy en egen utrustning. Några andra fritidssysselsättningar hade han inte. Tommy kommer främst ihåg den snedvridna stämningen i barnhemmet: det eviga ogillandet, massförödmjukelsen och instängningen i arresten. De som lydde bemöttes inställsamt, medan de som inte var omtyckta, såsom Tommy; blev utstötta. Följden var fördjupad bitterhet.

Tommys drogskulder hade ökat, och han planerade en större stöt med en kompis som han bekantat sig med i centrum av Tammerfors. Vid den tiden var tidningarna fulla av rapporter om rån mot guldsmedsaffärer. Även Tommy hade för avsikt att genomföra ett sådant rån. Guldsmedsplanen gick av någon anledning i stöpet, men i stället rånades en bank under hot av en leksakspistol. Bytet var 53000 mark som delades i två. En bil stals för transporten av bytet, man åkte till Tammerfors för att dela ut pengarna till fordringsägarna. Sedan åkte Tommy med ett nytt gäng till Köpenhamn - också vuxna deltog med tanke på tullformaliteterna. Tommy var då bara 15 . Bibliotekskortet var ett tillräckligt IDkort, och Köpenhamnsresan började. Det var meningen att resan skulle vara ett kort besök för anskaffning av hasch, men den förlängdes till två veckor $\mathrm{i}$ Christiania. Hemresan gjordes genom Sverige, och man hade med sig en avsevärd mängd hasch och starkare substanser. Kompisen som deltog i bankrånet hade blivit gripen och erkänt. En efterlysning väntade Tommy i Finland. Husundersökning hade gjorts hos Tommys mor som hade anklagats för att dölja Tommy. I tidningarna fanns noggrant signalement på Tommy vars rykte bland kompisarna ökade i takt med berömmelsen. Det fanns kompisar hemma i Finland, och man gav beredvilligt Tommy ett gömställe. Haschet blev utbytt i pengar, och man gav Tommy andra substanser, sprit och nya kläder. Han kunde lämna gömstället endast på nätterna. Han stod ut med trycket några veckor, men tröttnade snart på alltsammans och ringde olycklig till modern som lättad kunde konstatera att sonen var vid liv. Hon uppmanade honom att återvända till 
barnhemmet. Vilket Tommy gjorde. Tommys personliga vårdare i barnhemmet lovade underrätta polisen först nästa morgon - Tommy ville sova bort spänningen och utmattningen över natten. Men samma kväll gjorde polisen en framryckning till barnhemmet, och Tommy fördes på ett effektfullt sätt till häktet. De andra barnen stannade kvar i hemmet och kunde beundra den häftiga avfärden. Gripandet ledde givetvis till arrestering och häktningsrättegång. I polishäktet blev Tommy slagen med batong på fotsulorna tills han började tala. Det var omöjligt att gå till fots efter batongbehandlingen.

Tommy fördes till barnhemmet för att invänta rättegången. Där kunde han vara i fred, frånsett den dagliga anmälningsskyldigheten hos polisen. Resförbud hade också påförts. Tommy minns att han brukade sitta på en sten vid stranden, röka hasch och höra freestyle. Ingen ägnade honom någon uppmärksamhet. Vid rättegången yrkade en företrädare för barnhemmet att Tommy skulle dömas villkorligt och omedelbart överföras till pojkhemmet Pohjola i Muhos. Tommy hörde om överföringen första gången i tingssalen och minns att han själv hellre hade blivit intagen i fängelse för att avtjäna 1 år 8 månader. I ett fängelse hade han som förstagångsintagen endast varit tvungen att avtjäna hälften av straffet, relaterar Tommy sina minnesbilder från den dystra stämningen vid den tiden. Den första dagen i hemmet Pohjola blev Tommy slagen av femton pojkar i bastun. Det fanns ingen man kunde besvära sig hos. Han blev ännu några gånger kollektivt misshandlad i pojkhemmet innan han fattade ge tillbaka. Han hade ryckt med sig en stödkäpp från häcken på gården, och när han gav tillbaka med den, slutade misshandeln. Ryktet spred sig, och även de äldre pojkarna började sällskapa med honom. Tommy fantiserade om framgångsrika stötar, och man tänkte ut nya fantasier tillsammans. De andra grabbarna åkte gärna för att hämta tabletter i apoteket i centrum. Där kunde han också utan svårigheter skaffa olika slag av hostmediciner. Det blev nu en paus med de starkare substanserna. Skolan i pojkhemmet beredde inga svårigheter, inlärning hade alltid varit lätt för Tommy, och här kunde man själv framföra önskemål om siffrorna i betygen. Tommy föreslog sjuor och fick sådana. Visst kunde man studera mera flitigt, om man ville. Skidutflykter gjordes också, och det var kul. Det som särskilt kränkte Tommys identitet från första början var hårklippningen - han fick välja mellan att håret klipptes i obligatorisk ordning eller att han själv klippte av sin hästsvans. Tommy valde det senare, men den tråkiga tvångsåtgärden inetsade sig i minnet.

På somrarna skulle man jobba i pojkhemmet. Eftersom Tommy var storväxt, blev han kommenderad att skotta gödsel i stallet och borsta hästar. Minnet av detta förskräcker Tommy ännu denna dag, eftersom han som uppvuxen i stan var rädd för hästar, och hästarna var rädda för honom. Saken blev inte lättare av att den tuffaste instruktören i pojkhemmet skulle styra jobbet i stallet. Slag med hästpiskan ven mot låren om jobbet inte sköttes. Instruktören hade dessutom för 
vana att handleda pojkarna genom att kasta dem i hötravarna. Bitterheten ökade efter dessa incidenter, det gjorde skolkningen från pojkhemmet också. Man hittade på nya tricks under frånvaron. Det var lätt att stjäla bilar och råna folk i parkerna. Som en tillrättavisning överfördes Tommy till den strängaste enheten i pojkhemmet, styrd av ett instruktörspar som lämnade dystra minnen. Det äkta paret grälade oupphörligt, mannen slog hustrun i fyllan, och den äldste sonen mobbade barnen i pojkhemmet utan att någon ingrep. Vem hade trott på barnens ord. Den starkares rätt var den förhärskande ordningen i vardagslivet i pojkhemmet. Som ett hemskt exempel minns Tommy en pojke som skickats från sjukhuset i Mariefors. Den nye pojken instruerades i hemmets vanor med särskild iver, eftersom han hade en sjuklig benägenhet att tända eldsvådor, och det fruktade man på riktigt. Pojken stod inte länge ut med mobbningen, och en dag hade han hängt sig i vedboden. Den värste mobbaren fick ett epileptiskt anfall på grund av sina samvetskval. I övrigt förbigicks frågan med tystnad. Rymmarfärderna från Pohjolahemmet utsträcktes nu till Tammerfors. Under dessa färder hann man stjäla upp till tio bilar innan man greps och fördes till polishäktet. I pojkhemmet följde två veckors arrest i hemmets finka - tiden tillbringades i bara kalsongerna. På dagarna var det tillåtet att läsa bibeln på golvet. Bädden ställdes i ordning på kvällen. Man vistades utomhus i anstaltens overall med texten POKO (Pohjolan koulukoti, Skolhemmet Pohjola) tryckt på ryggen. Stövlarna var överdrivet stora. Avsikten var för att förhindra rymning.

Mannerheims barnskyddsförbund gjorde av och till besök i pojkhemmet på grund av enstaka klagomål. Men det var alltid "goda elever" som utvaldes till intervjuer, sortimentet på kaffebordet var rikligt, och de anställda i pojkhemmet var alltid närvarande. Pojkarna blev aldrig utfrågade på tu man hand. För Tommy begränsade sig de positiva sidorna av pojkhemmet till skidutflykterna, avgångsbetyget från grundskolan och jobbet tillsammans med instruktören i trädgårdsskötsel. I början av 1993 fyllde Tommy 17. Han hörde sig för om han kunde bli utskriven från pojkhemmet i början av sommaren om han beter sig oklanderligt. Tommy ville ihärdigt komma bort från hemmet och betedde sig $\mathrm{i}$ själva verket sig väl. Han skötte permissionerna och träffade turvis sin pappa och sin mamma i Tammerfors. Ansträngningarna kröntes med belöning, och Tommys mamma skaffade sonen en lägenhet $\mathrm{i}$ Tammerfors. Hästsvansen $\mathrm{i}$ håret hade vuxit ut igen, men förståndet hade inte vuxit. Det bekanta gänget samlades redan dagen för utskrivningen i den nya lägenheten med en stor säck amfetamin, sprit och tabletter. Det vilda livet började igen. Tommy kastade rentav ut sin mor när hon försökte göra ett besök. Han skulle minsann visa kompisarna vad han gick för! Sommaren förflöt med droger och brott. Tommys tankar upptogs av droger. Han blev bekant med LSD och var förtjust i drogen flera månader. Man prövade på allt annat mellan himmel och jord. Gänget gjorde en ny resa till 
Köpenhamn, och Tommy blev förtjust i heroin. Tommy kunde behålla lägenheten, eftersom hyran betalades av socialförvaltningen. Visst var han nykter emellanåt - han besökte sin pappa, och besöken var lyckade. Sommaren tog slut, och det hejdlösa drogbruket avbröts temporärt på den slutna avdelningen i sjukhuset i Pitkäniemi. Tommy blev intagen för två veckor och transporterades dit $\mathrm{i}$ ambulans av polisen. Hans enda oklara minne om saken är att polisen trängde in i lägenheten och att han vaknade upp i sjukhuset. Men inte ens denna erfarenhet stoppade honom. Han blev försedd med flera recept vid utskrivningen och upptäckte ett nytt praktiskt sätt att skaffa sig starkare mediciner.

Tommy hade beslutat sig för att fullgöra sin värnplikt. Även om han försenade sig till mönstringen, fick han en plats i ett jägarförband i gränstrakten kring Sodankylä. Han ryckte in 1995 och gick frivilligt till frisören före det. Han fullgjorde sina militära skyldigheter väl. Han klarade sig med hjälp av tabletter och cannabis. Lumpen var - till skillnad från tidigare anstaltsvistelser - en positiv erfarenhet för Tommy, här rådde rent spel. Visserligen försenade han sig under en permission när Finland, samtidigt som han tillbringade permissionen i Tammerfors, vann VM-guld i ishockey, och det måste firas. I förbandet arresterades han för förseningen och dömdes till nio dagar extra värnplikt. Det var sura dagar när de nya rekryterna anlänt och jägarkompisarna redan åkt. Han hade dessutom degraderats till B-klassen, men han hade trots allt sitt militärpass kvar och dessutom ett barn, resultatet av en permissionskväll. En annan familj tog hand om barnet, men det är en annan historia. Efter värnplikten blev Tommy anställd som anstaltshjälp på Koukkaniemi ålderdomshem i Tammerfors. Han var den ende manlige vårdaren. Även om han som en storväxt karl hade till uppgift att lyfta de tyngre gubbarna och gummorna, tyckte han om jobbet. Pratstunderna med de gamla lämnade en känsla av välbefinnande, trots alla byten av blöjor.

Tommy måste lämna jobbet när hans första ovillkorliga fängelsestraff skulle verkställas. Han fick avtjäna straffet i den öppna anstalten i Toijala där han ett halvt år kunde studera i handelsskolan. Han fortsatte studierna efter frigivningen och avlade nästan examen. Han tyckte om studierna. Men hans gamla läggning kom att ta sig uttryck i ett försäkringsbedrägeri. Det fanns dessutom två försök till skadegörelse och ytterligare narkotikabrott. Han hade många ackumulerade skulder för drogbruket. Inkassering och försäljning var det enda sättet att täcka skulderna. Det var tungt, men det fanns inget annat sätt att skaffa sig pengar. Ingenting förändrades i Tommys liv under den andra intagningen i Riihimäki fängelse. Visst gav den honom en chans att pusta ut, men redan en vecka efter frigivningen blev han intagen på intensiven i Tammerfors centralsjukhus. Han skulle driva in drogskulder och hade blivit ordentligt slagen. Njurarna avstannade för ett ögonblick - hans fysik gick helt enkelt i strejk. På intensiven blev han dessutom infekterad av en sjukhusbakterie. Den stora adduktorn måste avlägsnas. 
Illamåendet förbättrades visserligen av de "egna läkemedel" som kompisarna flitigt hade med sig på besöken. På sjukhuset magrade Tommy 49 kilo, modern hade tagit ett kort på honom. Hon besökte ofta sjukhuset - till fängelset kom hon aldrig.

Tommy måste nu t.o.m. lära sig att gå på nytt i AA-gillets hem. Han vistades där åtta månader utan några droger - den längsta avgiftningsperioden $\mathrm{i}$ hans liv än så länge. Efter att ha skrivits ut från härbärget 1999 fick Tommy en egen lägenhet och jobb. Drogmissbruket förblev obetydligt, men ersattes med alkohol. Han sällskapade stadigt och bodde ihop med sin sambo flera månader. Samlivet försvårades av sambons abnorma svartsjuka. Ångesten och påfrestningen som orsakades av misstänksamheten tog sig på hösten uttryck i drogmissbruk. I ett förvirrat psykiskt tillstånd blev Tommy på en krogrunda förbannad på en man $\mathrm{i}$ hans sällskap och stötte till denne med en kniv. Tommy övervägde incidenten ett dygn hemma, han berättade den för sin sambo och begav sig till polisdistriktet för att erkänna. Med sig hade han substitutsubstanser och tabletter. Medan han satt häktad i Kylmäkoski fängelse, blev ångestkänslan lättare med hjälp av kokain, heroin och substitut. Rättspsykiatriska undersökningar genomfördes både i Lappvikens sjukhus i Helsingfors och i utplaceringsenheten i Åbo fängelse. Gängbildningstrycket i fängelserna är starkt, Tommy gav efter och blev "omhändertagen". Han hade inte brytt sig om omhändertagandet, men var och en har sin egen ställning i ett fängelse. Hans humör blev inte bättre när han fick veta att sambon bedrog honom, men han fick henne att berätta sanningen. De kunde komma överens om separation, och fängelsetiden blev därmed lättare. De kom överens om vården av deras gemensamma barn. Även Tommys föräldrar deltog från första början i omsorgen om den lilla dottern, det gjorde också Tommy. Han säger att han trots separationen förstår modern till dottern bättre på grund av hennes svåra bakgrund. Efter att ha fått sina hemförhållanden i ordning började Tommy frigöra sig från de förvridna inslagen i fängelselivet, även om det var varken lätt eller gratis. Han funderade på sin framtid. Han hade inga möjligheter att få permission, inget hopp om att bli överförd till öppen anstalt. Han var verkligen trött. Minnet av tiden i Kylmäkoski fängelse påminner Tommy alltjämt om den eviga onda cirkeln: knarkförsäljning, utpressning, ocker, tvång - många olagliga förehavanden. Tommy ville frigöra sig från allt det där. Nån hade berättat - det var nån före detta drogmissbrukare, tror Tommy - om gruppvården Kisko som man kunde ta kontakt med under anstaltstiden. Denna information stannade i Tommys undermedvetande.

Tommy beviljades i sinom tid permission och var väldigt glad när han kunde träffa sitt barn. Han använde inga starka substanser - bara alkohol då och då. Senaste höst fick han ett återfall under en permission - polisen förde honom tillbaka till anstalten, och allting måste börjas om igen. Han kom igen att tänka på gruppvården Kisko. Han skrev en ansökan tillsammans med missbrukarvårdaren i 
fängelset, och efter en två veckors avgiftningsperiod på fängelsesjukhuset började han den 24 november 2003 delta som elev, så kallas deltagarna, i en vårdgrupp på Kiskoavdelningen i Kervo fängelse. Tommy tror nu på sig själv och är övertygad om att han kan kan klara av hela vården som är indelad i tre faser. Han skall börja den andra fasen nästa sommar i en liknande vårdgrupp i friheten. Det är just den gruppen som tjänade som exempel när Kervo fängelse gick in för gruppvårdmodellen för sju år sedan. Efter att vårddiagnosen ställdes har Tommy blivit ledigare, öppnare och gladare - nervositeten från de första månaderna har försvunnit. Tommy har känt att gruppvården i fängelset är viktig med tanke på både drogfriheten och inlärningen av andra färdigheter i livet. Han ser att det finns mycket han inte har lärt sig, ända från barndomen. Nu har han en möjlighet att koncentrera sig på andligt viktiga frågor, sakernas rangordning och sitt beteende, räknar han upp. Det bästa är att han lärt sig lita på människor - han sätter värde på gemenskap och säger att det är just den som uppfostrat honom att bli osjälvisk. Tommy vill ännu betona vikten av hjälp från likställda i självhjälpgrupperna (NAgrupperna) som besöks av eleverna från Kiskoavdelningen i Kervo. Även av dessa grupper har han fått mycket, säger han.

\section{Fängelsedirektörens reflektioner}

Som direktör för Kervo ungdomsfängelse - i dag Kervo fängelse - har jag hört tiotals, ja hundratals, erfarenheter som påminner om denna sanna historia. Det har jag gjort, när jag intervjuat unga gärningsmän, men även vuxna intagna, som skickats till oss från olika delar av Finland. Dömda fångar från hela södra Finland har avtjänat sitt straff $\mathrm{i}$ vår anstalt under hela dess historia. Men från och med slutet av nittiotalet har vi dessutom haft ett ökande antal utländska fångar och barn från invandrarfamiljer, bl.a. från Estland. De unga - dvs. de som begått sitt brott innan de fyllde 21 - bildar en egen enhet i anstalten, men i många jobb och under utbildningen tillbringar unga och vuxna fångar en stor del av tiden tillsammans.

Riskfaktorerna i utslagningen av barn och unga upprepas enligt min erfarenhet gång på gång. De återspeglas - i de intervjuer jag gjort och i mina andra erfarenheter av interaktion och umgänge - som en summa av samma faktorer. Ibland spelar några faktorer en större roll, ibland en mindre, än i fallet Tommy.

I några hem finns det en större ackumulation av våld, rusmedelsbruk, arbetslöshet, psykiska problem, flyttningar, divergerande vanor och kulturer samt splittrade och ombildade familjer - $\mathrm{i}$ andra familjer en mindre.

När det gäller barn, i synnerhet barn av Tommys typ som är livliga och begåvade, upprepas riskfaktorerna i form av beteendestörningar och skolsvårigheter. Dessa åtgärdas på ett högst varierande sätt och ofta med partiella lösningar. Ofta sker det så att barnets eller den unges skola byts ut, medan familjens övriga situation förblir oförändrad. I några fall uppskjuts ingripandet ända tills 
åldern för straffrättsligt ansvar börjar. När det gäller femtonåringar, tycks man vänta sig att straffrättsliga metoder skall lösa de problem som länge ackumulerats i familjerna.

Barnskyddslagen är relativt ny i Finland, den härstammar från början av 1980-talet. Utan att närmare befatta mig med hur välfungerande lagen är eller de villkor den erbjuder, har jag utifrån mina erfarenheter varit tvungen att begrunda om lagens syfte snarare är att skydda föräldrarna än att skydda barnen.

Jag vill ingalunda förneka familjens och föräldrarnas betydelse. Men om föräldrarna eller en ensamförälder saknar de resurser som kan garantera en uppväxtmiljö som överensstämmer med barnets intressen, skall familjen inte uppfattas som ett område som är in i det sista heligt - så heligt och okränkbart att det blir omöjligt att i rätt tid överväga möjligheten av ett konstruktivt ingripande.

Detta betyder i praktiken att vi måste skapa ett övergripande stödsystem för familjerna. Ett sådant system måste grunda sig på ett mångårigt samarbete mellan myndigheter, frivilligorganisationer, församlingar och familjer. Det är inte lätt att inleda ett samarbete med motvilliga familjemedlemmar, eftersom det ofta gäller viktiga pengar, t.ex. barnbidrag till vuxna barn i en familj och andra bidrag. Det är inkomstkälla man inte gärna vill avstå från.

När barnens intressen skall prioriteras och när barnen skall höras på rätt sätt, behöver vi allsidigt kunnande. Barn är oändligt lojala mot sina biologiska föräldrar. Omhändertagande och utplacering i främmande familjer eller anstalter är inte alltid någon garanti för att barn skall bli behandlade på ett adekvat sätt och för att deras divergerande behov skall beaktas. När det gäller unga i pubertetsåldern tycks det vara särskilt svårt att finna den riktiga lösningen. Resultaten av lösningar som på ett eller annat sätt varit misslyckade, och som med andra ord åstadkommit unga och vuxna som till slut hamnat i fängelse, försöker vi för vår del hjälpa genom att erbjuda dem möjligheter till en bättre livshantering. Men det sker först i fängelset.

\section{Några drag i det finländska påföljdssystemet för unga}

I det finländska rättssystemet har de alternativa påföljderna när det gäller unga som begick ett brott innan de fyllde 21 länge varit desamma som när det gäller vuxna gärningsmän. Påföljderna har med andra ord varit böter, villkorligt fängelse och slutligen ovillkorligt fängelse. Den som begått ett brott innan han eller hon fyllt 21 kan emellertid ådömas övervakning som ett tilläggsstraff vid sidan av villkorligt fängelse. Över två års fängelse är alltid ett ovillkorligt straff, oavsett gärningsmannens ålder. Dessutom finns det en, delvis reformerad, särskild lag som gäller unga gärningsmän - lagen om unga förbrytare (262/1940).

Enligt denna lag som antogs för över 60 år sedan och som betonar nödvändigheten av fostrande inverkan på de unga skall gärningsmän som inte 
fyllt 15 år överföras från domstolarna till barnskyddsmyndigheterna. Med en ung gärningsman avses i 1 § någon som fyllt 15 men inte 21 år när han eller hon begick den straffbara gärningen. Enligt 14-16 § skall en ung gärningsmans ärende utan dröjsmål hänskjutas till fängelsedomstolen, när han eller hon dömts till minst sex månaders och högst fyra års fångelse för ett eller flera brott och straffet skall verkställas. Ett straff skall vidare förordnas att avtjänas i ett ungdomsfängelse, om det finns grundad anledning att anta att den dömde behöver den uppfostran och utbildning som kan erbjudas i ett ungdomsfängelse och att han eller hon är utvecklingsduglig. Den som fyllt 23 år får inte förordnas till ungdomsfängelse. Enligt 5 kap. $9 \S$ lagen om verkställighet av straff (39/1889) kan den som är intagen i ungdomsfängelse friges villkorligt, när han eller hon har avtjänat en tredjedel av straffet, inklusive det avdrag som domstolen med stöd av 3 kap. $11 \S$ strafflagen gjort.

Möjligheten att frige unga fångar villkorligt efter att de avtjänat en tredjedel av straffet har blivit automatisk praxis. I takt med den nya fängelselagen som enligt planerna skall träda i kraft i början av 2006 skall denna nedsättning slopas.

I 8 § strafflagen (515/2003) som gäller straffskalan konstateras det att en lindrigare straffskala skall tillämpas vid bestämning av straff, om gärningsmannen begått sitt brott innan han eller hon fyllt 18 år.

Genom en lagändring som trädde i kraft 1990 reformerades lagen om villkorligt fängelsestraff så att en dom till ovillkorligt fängelse för brott som begåtts innan gärningsmannen fyllt 18 år kräver vägande skäl. I motiveringen till regerings-propositionen (RP 245/1988 rd) konstaterades det att tron på fängelsestraffets botande inverkan hade minskat, eftersom ovillkorligt fängelse är en mera ofördelaktig påföljd med avseende på återfallsrisken.

Tack vare lagändringen minskade de ovillkorliga straff som ådömts unga som inte fyllt 18 år avsevärt. Antalat unga som inte fyllt 18 har efter lagändringen i genomsnitt varit under tio i det dagliga fångtalet.

Åklagaren har också en särskild möjlighet att avstå från vidare åtgärder, dvs. att meddela åtalseftergift, när det gäller gärningsmän som inte fyllt 18. Enligt 1 kap. $7 \S 2$ punkten lagen om rättegång i brottmål (689/1997) får allmänna åklagaren besluta att inte väcka åtal för ett brott som begåtts av någon som inte har fyllt 18 år, om det inte kan förutses medföra ett strängare straff än böter eller fängelse $\mathrm{i}$ högst sex månader och gärningen kan anses ha snarare berott på oförstånd eller förhastande än på likgiltighet för förbud och påbud i lag.

Domstolen kan enligt 6 kap. $12 \S 2$ punkten strafflagen (315/2003) avstå från att döma en gärningsman till straff när gärningsmannen har begått sitt brott innan han eller hon fyllt 18 år och gärningen kan anses ha berott på oförstånd eller förhastande. 
Genom att avstå från vidare åtgärder när det gäller brott som begåtts av unga gärningsmän kan man även uppnå andra mål vid sidan av lindrigare straffmätning för gärningar som beror på oförstånd eller förhastande. Ibland kan påföljder som inte ingår i det straffrättsliga systemet, exempelvis åtgärder som vidtas av barnvårdsmyndigheterna eller skadeståndsförlikning, vara ändamålsenliga med hänsyn till förebyggandet av kommande brott.

Samhällstjänsten som under nittiotalet beskrevs som lyckad är ett alternativ till fängelse. Men den är inte särskilt riktad till de unga. Lagen om försöksverksamhet med ungdomsstraff (1058/1996) trädde däremot i kraft den 1 februari 1997 och är uttryckligen inriktad på unga som inte fyllt 18. Experimentet har genomförts i åtta tingsrättsdistrikt. Den viktigaste avsikten med reformen var att introducera en meningsfull påföljd genom vilken nackdelarna med ovillkorligt fängelse skall kunna undvikas. Påföljden består av ungdomstjänst och övervakning. Ungdomstjänsten skall närmare definieras separat.

Man är inte lika övertygad om hur väl experimentet fungerar, jämfört med samhällstjänsten. Experimentets innehåll utvecklas för närvarande, och det utvidgas så att det skall täcka hela Finland.

Detta är några drag i det finländska systemet. Många frågor måste naturligtvis lämnas utanför min framställning. Ett exempel är det intressanta experimentet med påskyndad behandling av brott som begåtts av unga och de positiva resultat vi har av experimentet.

Min framställning är givetvis avgränsad. Den är mera fokuserad på praktisk erfarenhet än på teori.

\section{Om fängelsets möjligheter}

Hur skall vi då i det dagliga fängelsearbetet kunna uppnå de mål som ställts upp för fångvården? Ett straff skall ju verkställas så att det inte i onödan försvårar, utan i mån av möjlighet främjar, de intagnas återanpassning i samhället. Och när straff som ådömts unga gärningsmän verkställs, skall särskild vikt fästas vid de särskilda behov som beror på den intagnes ålder och utvecklingsstadium.

Vid sidan av traditionellt arbete, studier och den alltid närvarande kontrollen finns det i dagens läge olika övergripande livshanteringsprogram av varierande slag och längd i alla fängelser. Kervo fängelse uppskattas i dag som en djärv pionjäranstalt när det gäller tillämpning av sådana och andra åtgärdsprogram. Tillämpningen av systematiska program i anstaltsverksamheten fick en betydelsefull impuls för drygt sju år sedan, när Penningautomatföreningen gjorde det möjligt att starta ett missbrukarprojekt bland fångarna.

De allvarliga skador för hälsan (bl.a. HIV) som uppstod på grund av bruket av starka droger väckte samarbetsberedskapen hos myndigheterna. Med stöd från Penningautomatföreningen kunde fängelserna själva välja sina samarbetspartners 
i missbrukarvården bland sakkunniga vårdenheter och -samfund. Vi i Kervo började samarbeta med Finlands äldsta sjukhus för missbrukare, Träskända socialsjukhus. Detta samarbete har efter att projektet avslutades burit frukt i programmet "Bortom gallren", en viktig del av vår verksamhet. Programmet "Bortom gallren" är registrerat som ett kognitivt-behavioristiskt systematiskt vårdprogram. Det är avsett för grupper som består av mellan sex och sju personer. Programmet är fokuserat på behandling och korrigering av tanke- och handlingsmodeller som upprätthåller den onda cirkeln av missbruk och kriminalitet hos de intagna. Programmet varar 120 timmar eller fyra veckor, dock så att tidtabellen för fullföljandet vid behov kan skräddarsys så att programmet kan pågå t.o.m. ett halvt år. Då omfattar kursen studier, arbete eller något annat som är viktigt för just den gruppen.

Vi har tillsammans med instruktörerna från Träskända sjukhus bearbetat och til??lämpat kursen som en referensram anpassad till de unga intagnas behov. Samtidigt har vi själva studerat detta kunnande så att någon av våra anställda kontinuerligt deltar i utbildningen.

I vårt s.k. Work Out Project som stöds av den europeiska fonden för sociala frågor betonar vi hur viktigt det är att inkludera familje- och stödnätverk redan under fängelsetiden. På detta sätt kan vi säkerställa övergången till friheten. Det särskilda ungdomsarbete som församlingen i Helsingfors utför är en viktig kunskapskälla och ett stort stöd för oss i arbetet med familjer. Finansieringen av detta treåriga projekt utvidgades nyligen med tre extra år.

Kursen "Bättre tålamod utan droger" är särskilt fokuserad på våldsbrott som begås av unga. I kursen ingår också en bearbetad del av programmet "Bortom gallren". Under kursen skall deltagarna lära sig att undvika våldsamma beteendemodeller genom att öva in alternativa modeller i konkreta situationer. Att bearbeta känslor och beakta andra människor är en viktig del av arbetet på kursen "Bättre tålamod utan droger". Också handledd motion spelar en viktig roll i många avseenden. Vid sidan av Träskända socialsjukhus samarbetar vi i detta program dessutom med en instruktör från en frivilligorganisation som har mångårig erfarenhet av arbete med unga på gatorna och inlärning av våldsfria alternativa levnadsmönster. Eftersom strafftiden för de unga i genomsnitt är ca åtta månader, har programmet "Bortom gallren" visat sig vara synnerligen användbart. Att garantera kontinuiteten av programmet efter frigivningen är för närvarande ett av våra viktigaste mål.

En annan viktig samarbetspartner från tiden för missbrukarprojektet bland fångarna är Kiskoenheten vid Kalliolaklinikerna. Enheten har en mångårig erfarenhet av jobb med missbrukare och särskilt av hur man skall gå till väga $\mathrm{i}$ gruppvård. Den registrerade gruppvårdmodellen i vår egen anstalt fyller snart sju år. Vår modellenhet har snart tjugo år arbetat med den första långvariga vårdmo- 
dellen för drogmissbrukare, och resultaten är goda. Vi samarbetar kontinuerligt med denna civila enhet, och båda parterna har dragit nytta av samarbetet. Vi samlas ofta - det gäller både de anställda och eleverna från grupper på olika nivåer - för att fira gemensamma gruppvårddagar.

Vår avdelning för Kiskovård har nio platser. Den är isolerad från det övriga fängelset. Vårdtiden är i genomsnitt sex månader. Därifrån övergår man till den andra fasen i en öppen anstalt. Den tredje fasen genomförs i Kiskoenheten för eftervård i Kalliolaklinikerna. Intensivprogrammet varar totalt mellan arton och tjugofyra månader. Men även efter detta är eftervården en viktig del av rehabiliteringsprocessen. Syftet med rehabiliteringsprogrammet är att garantera drogfrihet, lära ut ett levnadssätt utan droger och ge motivering till ett livslångt växande. Vårdprogrammet bygger på hierarkisk gruppvård av Daytopmodellen enligt vilken eleverna själva skall sköta sina dagliga aktiviteter utifrån ett fast dags- och veckoprogram. De funktionella och terapeutiska grupperna, inklusive de emotionella, ingår som väsentliga delar i varje enskild fas i denna modell som genomförs utan mediciner. Varje enskild elevs personliga växande skall stödjas med grupp- och individuell terapi. Personalutbildningen i detta krävande program är fortgående. Det är också handledningen.

Stämningen på avelningen är positiv. Programmets uppmuntrande interaktiva angreppssätt representerar den bästa fångvård jag nånsin sett. Programmet är avsett för alla åldrar, men än så länge har medelåldern klart överskridit tjugoårsgränsen. Antalet intagningar är i medeltal fem hos eleverna. De jobbar i trädgården i Kervo fängelse. Varje elevs individuella ansvarsområde bestäms av trädgårdsmästaren.

I friheten har denna gruppvårdmodell tillämpats drygt ett år på unga i Helsingfors som är mellan 14 och 17 och som blivit omhändertagna. De är klienter hos barnvården och har allvarliga missbruksproblem. Denna psykosociala rehabilitering har även givit ett särskilt stöd till olika nätverk av unga missbrukare. Den har ökat deras kunskap om drogberoende och erbjudit olika livshanteringsmodeller och stöd till föräldraskap.

Efter att ha bekantat mig med denna enhet för unga är jag övertygad om att denna gruppvårdmodell utan tvivel är ett synnerligen effektivt sätt att angripa de problem jag ovan beskrev. Det finns även andra lösningsmodeller och -sätt. Men det viktigaste i alla tillvägagångssätt är sunt mänskligt stöd och omsorg från en vuxen. Och det måste komma i ett så tidigt skede som möjligt.

Adress:

Kervo fängelse

PB 133

FI-04201 Kervo

E-post: kirsti.nieminen@om.fi 